\title{
Treatment of Pulmonary Embolism: a Decade of Experience
}

\author{
Nikonenko A. ${ }^{1,2}$, Nikonenko A. ${ }^{2}$, Matvieiev S. ${ }^{2,3}$, Osaulenko V. ${ }^{1,3}$, Nakonechniy S. ${ }^{1}$ \\ ${ }^{1}$ Zaporizhia Medical Academy of Post-Graduate Education Ministry of Health of Ukraine, Zaporizhzhia, Ukraine \\ 2Zaporizhzhia State Medical University, Zaporizhzhia, Ukraine \\ ${ }^{3}$ Zaporizhzhia Regional Clinical Hospital, Zaporizhzhia, Ukraine
}

\begin{abstract}
Summary. Pulmonary embolism (PE) is a major life-threatening illness which remains one of the main causes of sudden death throughout the world. The analysis of diagnosis and treatment of 472 patients with acute pulmonary embolism for a period of 10 years was performed. High efficiency of diagnosis using multispiral computer angiopulmonography (MSCT APG) has been established, thus this method completely supersedes the traditional selective angiopulmonography.

Seventeen $(3.6 \%$ ) patients died due to PE recurrence, another $8(1.7 \%)$ patients died due to the bleeding after using fibrinolytics and anticoagulants, and $14(2.9 \%)$ died due to progression of organs failure. This emphasizes the need to improve measures aimed to prevent PE recurrence and identify sources of possible bleeding and refrain from aggressive fibrinolytic therapy.

The use of differentiated approach to the treatment with thrombolytic therapy and anticoagulants enabled to achieve recovery in $433(91.7 \%)$ patients who were discharged for outpatient treatment. New oral anticoagulants were prescribed to $94(21.7 \%)$ patients after discharge.
\end{abstract}

Keywords: pulmonary embolism; computer tomography; anticoagulants; thrombolysis; recurrent pulmonary embolism.

Introduction. Pulmonary embolism (PE) is a lifethreatening pathological condition caused by derangement of blood flow in the pulmonary artery due to embolism by thrombi mainly from the system of the lower vena cava. It is the most dangerous complication of venous thrombosis of the lower extremities $[1,3]$. The incidence ranges from 75 to 269 cases per 100,000 population per year in Western Europe, North America, Australia, and Latin America [2, 3].

PE occupies a special position among other critical conditions. And to date, a number of problems of diagnosis, treatment and prevention remains unresolved. For reliable diagnosis, angiography or computer tomography is required. Multi-spinal computer angiopulmonography (MSCT APG) allows not only to establish correct diagnosis, but also to conduct differential diagnosis between thrombotic and non-thrombotic embolism [4]. Effective treatment of massive pulmonary embolism is possible only through the use of potentially dangerous thrombolytics, or by performing thrombembolectomy from the pulmonary artery with an artificial blood circulation device. Even in the developed countries, the level of mortality due to PE remains high and ranges from 7 to $11 \%$ [5]. Despite preventive measures, PE regularly occurs in surgical and therapeutic hospitals, and there is also a high level of recurrent PE in the distant period after discharge. Thus, improvement of the treatment of patients with PE remains one of the most important problems of modern medicine [3].
Aim. To improve the methods of diagnosis and treatment of PE by analyzing the ten-year experience of care of patients suffering from this abnormality.

Materials and methods. To study the results of diagnosis and treatment of acute PE, inpatient medical records for the period from 2008 to 2018 were processed.

In total, 472 patients have been treated for ten years. The average age was $60.7 \pm 14$. There was a slight prevalence of men over women: 255 versus $217(p=0.07)$. All the patients were admitted urgently and were hospitalized to the intensive care unit. In addition to standard clinical methods, selective angiopulmonography (APG) was carried out in 222 (47\%) patients, and MSCT APG in $238(50.4 \%)$ patients for the final validation of PE. In $12(2.5 \%)$ patients, PE at the time of hospitalization was diagnosed on the basis of clinical data and electrocardiogram (ECG) and chest Xray or echocardiography (ECHO CG), since the extremely critical condition impeded transportation of these patients before final verification by means of APG and MSCT APG. According to the obtained data, the diagnosis of non-massive, submassive and massive PE was established. For such a division, the principle of counting the embolism index proposed by G. A. H. Miller in 1971 was used. According to this method, the diagnosis of non-massive pulmonary artery disease was established at an index of 1 to 16 , submassive - from 17 to 21 , massive -22 and higher. In patients with non-massive PE only anticoagulants were prescribed, and in patients with submassive and massive PE 


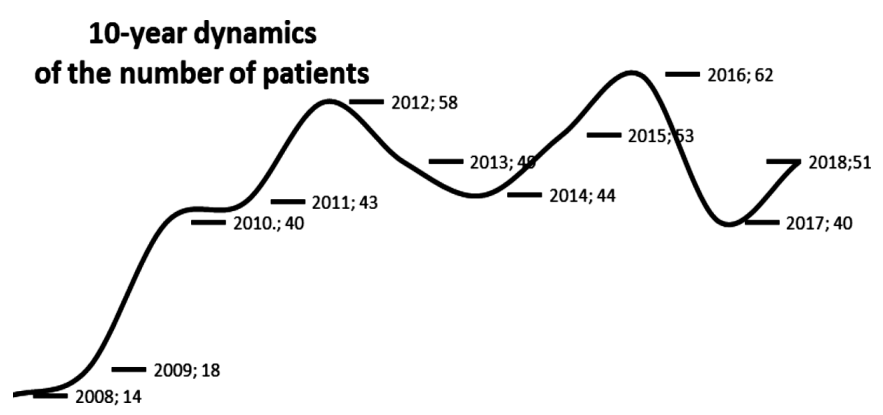

Figure 1. Dynamics of the annual number of patients hospitalized with pulmonary embolism

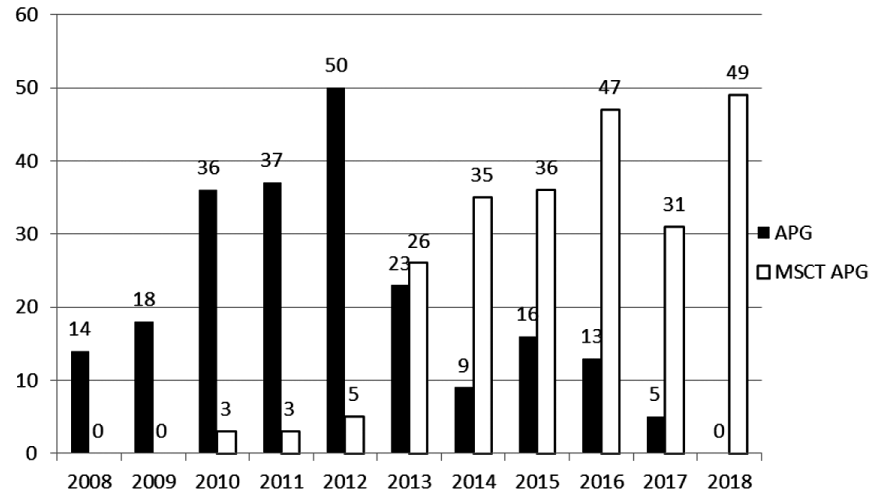

Figure 2. Dynamics of $A P G$ and MSCT APG use in the primary diagnosis of $P E$

The cases of death due to PE recurrences, as well as from bleeding, should be considered more closely as those that could be warned.

Seventeen $(43.6 \%)$ patients died from PE recurrence; two $(5.1 \%)$ cases were reliably confirmed by APG, in other cases the recurrence was clinically detected. Of all $17 \mathrm{pa}-$ tients who died from PE recurrence, only one $(5.9 \%)$ had floating thrombus before the recurrence; in two (11.8\%) patients, no signs of unstable blood clots were detected. Other $14(82.4 \%)$ patients did not undergo ultrasound examination of the veins of lower extremities due to inaccessibility of this study and, accordingly, there was no information about the presence of dangerous blood clots.

Eight $(1.7 \%)$ patients died from severe hemorrhage due to thrombolytics. Of these 8 patients, $4(50 \%)$ patients died after streptokinase administration, 3 (37.5\%) after alteplase and $1(12,5 \%)$ after heparin therapy. By the source of fatal bleeding, the patients were distributed as follows: $2(25 \%)$ patients died due to gastrointestinal bleeding; 2 (25\%) due to hemorrhagic stroke; 2 (25\%) due to pulmonary bleeding; $1(12.5 \%)$ due to bleeding from surgical wounds; $1(12.5 \%)$ due to bleeding from the oro- and nasopharynx.

For 10 years, there were 14 (36\%) fatal cases due to cardiac and respiratory failure progression. The average age of these patients was $66 \pm 14$ years, while the average age of surviving patients was $60 \pm 13.6, p=0.09$ : there is a trend towards older age in patients who died. At the same time, the dead patients had higher average duration of the disease before being hospitalized. In discharged patients duration of the disease was significantly longer in the dead patients: $5.9 \pm 13.6$ days in the discharged patients and $10.5 \pm 12.5$ days in the dead, $\mathrm{p}=0.02$.

As may be seen from the chart, bleeding and PE recurrence remain the factors leading to fatal outcomes.

After transfer from the intensive care unit, $339(78.3 \%)$ patients were assigned to VKA, and $94(21.7 \%)$ to NOACs. 


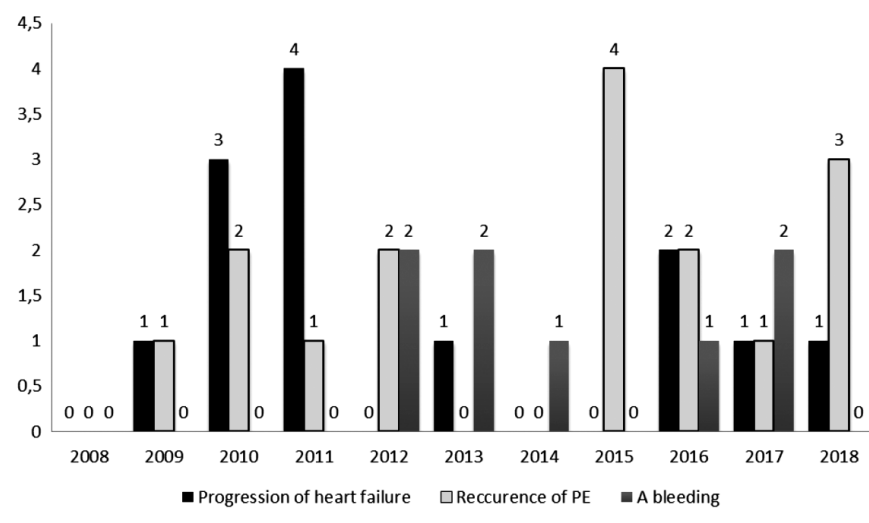

Figure 3. Distribution of patients by the causes of death by years

Discussion. Analysis of the dynamics of the number of patients with PE for ten years revealed the increase in the number of patients from 2008 to 2010, and further the number of patients varied in the range from 40 to 60 . This dynamics may be explained by the improvement of PE diagnosis due to the wider implementation of the MSCT APG since 2010. As the MSCT APG is less invasive and does not require special skills, the possibility to detect PE has appeared in all the institutions where CT scanners and related software are available.

Due to the use of the embolism index in MSCT APG and Miller's index in APG, the choice between anticoagulant and thrombolytic therapy was simplified. This allowed avoiding unreasonable risk in the use of thrombolytics in non-massive PE and reducing the level of fatal hemorrhagic intracranial hemorrhage to $0.4 \%$ with global mortality of up to $2 \%$ [3].

As a result of treatment, $433(91.7 \%)$ patients were discharged with improvement with normal hemodynamics and oxygen saturation. Thus, the results of PE diagnosis and treatment was satisfactory. Mortality rate of $8.2 \%$ corresponds to the global level from 7 to $11 \%$ [5], and there is no trend to increase. Taking into account eight cases of death due to fatal blood loss, the sources of possible bleeding should be identified more carefully. If these are detected, fibrinolytic therapy should be avoided and anticoagulants and surgical treatment should be used. In view of 14 (2.9\%) cases of recurrent PE that resulted in death, ultrasound examination of the lower limb veins should be performed as soon as possible to detect embolus threatening floating thrombi.

\section{Conclusions}

1. MSCT APG has shown high accuracy in detected PE, as well as additional capabilities for the detection of concomitant pathology and differential diagnosis.

2. Thrombolytic therapy quickly and reliably improves general condition of patients.

3. First of all, it is necessary to identify embolus threatening thrombi as soon as possible to prevent recurrence.

4. Both Vitamin K antagonists (VKA) and NOACs are feasible for secondary prevention of PE.

\section{References}

1. Konstantinides SV, Barco S, Lankeit M, Meyer G. Management of Pulmonary Embolism: An Update. J Am Coll Cardiol. 2016 Mar 1;67(8):976-90. https://doi. org/10.1016/j.jacc.2015.11.061

2. Raskob GE, Angchaisuksiri P, Blanco AN, Buller H, Gallus A, Hunt BJ, et al. Thrombosis: a major contributor to global disease burden. Arterioscler Thromb Vasc Biol. 2014 Nov;34(11):2363-71. https://doi.org/10.1161/ ATVBAHA.114.304488

3. Konstantinides SV, Torbicki A, Agnelli G, Danchin N, Fitzmaurice D, Galiи N, et. al. 2014 ESC Guidelines on the diagnosis and management of acute pulmonary embolism: the Task Force for the Diagnosis and Management of Acute Pulmonary Embolism of the European Society of Cardiology (ESC). European Heart Journal. 2014;35(43):3033-73.

4. Rudik MV, Rudik IV. Pulmonary embolism by foreign bodies: a case report. Zaporozhye medical journal. 2018;20(6):873-876. Russian.

5. Leibfried M, Falbaum S, Palummo J, Dickinson F. Treatment of Pulmonary Embolism. US Pharm. 2018;43(7): HS2-HS12.

\section{Десятирічний досвід лікування тромбоемболії легеневої артерії Никоненко О. С. ${ }^{1,2}$, Никоненко А. О. ${ }^{2}$, МатвєєВ С. О. ${ }^{2,3}$, Осауленко В. В.1, ${ }^{1,}$, Наконечний С. Ю. ${ }^{1,3}$ \\ ${ }^{1}$ ДЗ «Запорізька медична академія післядипломної освіти МОЗ України», м. Запоріжжя, Україна 23апорізький державний медичний університет, м. Запоріжжя, Україна ЗЗапорізька обласна клінічна лікарня, м. Запоріжжя, Україна}

Резюме. Тромбоемболія легеневої артерії (ТЕЛА) залишається однією з основних причин раптової смерті у світі. Рівень захворюваності на венозний тромбоемболізм не має тенденцій до зниження.

Мета роботи. Поліпшити методи діагностики та лікування ТЕЛА шляхом проведення аналізу десятирічного досвіду надання допомоги при цій патології.

Матеріали та методи. Проведено аналіз діагностики та лікування 472 пацієнтів 3 гострою ТЕЛА за період 10 років у відділенні кардіохірургії Запорізької обласної клінічної лікарні. Діагноз ТЕЛА було верифіковано за допомогою селективної ангіопульмонографії (АПГ) у 222 (47 \%) пацієнтів та мультиспіральної ком'ютерної 
ангіопульмонографії (МСКТ АПГ) у 238 (50,4 \%) пацієнтів. На основі клінічної картини та даних додаткових методів дослідження визначали масивну, субмасивну та немасивну ТЕЛА.

Для лікування пацієнтів з масивною та субмасивною ТЕЛА призначали тромболітичну терапію та хірургічне лікування. Для лікування немасивної ТЕЛА та в разі протипоказань до застосування тромболітиків - антикоагулянтну терапію з використанням тромболітиків, антикоагулянтів та хірургічного лікування.

Результати та обговорення. Відзначено високу ефективність діагностики з виконанням МСКТ АПГ, тому цей метод повністю витіснив традиційну АПГ. Від рецидиву ТЕЛА загинуло 17 (3,6 \%) пацієнтів, 8 (1,7 \%) - від кровотечі після застосування фібринолітиків і антикоагулянтів. Це вказує на необхідність покращення заходів для запобігання рецидивам ТЕЛА та виявлення джерел можливої кровотечі й утримання від агресивної фібринолітичної терапії. Завдяки диференційованому підходу до лікування з використанням тромболітичної терапії та антикоагулянтів досягнуто одужання у 433 (91,7 \%) пацієнтів, які були виписані на амбулаторне лікування. Із них 94 (21,7 \%) пацієнтам після виписування призначали нові пероральні антикоагулянти.

\section{Висновки}

1. МСКТ АПГ продемонструвала високу точність при визначенні ТЕЛА та додаткові можливості для виявлення супутньої патології та під час диференціальної діагностики.

2. Тромболітична терапія дозволяє швидко та надійно поліпшити загальний стан пацієнтів.

3. Насамперед потрібно якнайшвидше виявляти емболозагрожуючі тромби для профілактики рецидивів.

4. Для вторинної профілактики ТЕЛА доцільно застосовувати як антагоністи вітаміну К, так і нові пероральні антикоагулянти.

Ключові слова: тромбоемболія легеневої артерії, комп'ютерна томографія, антикоагулянти, тромболізис, рецидивна ТЕЛА.

Стаття надійшла в редакцію 10.04.2019 р. 